\section{Jörgen Vijgen}

Thomas Instituut Utrecht, Tilburg School of Catholic Theology

jorgen.vijgen@skynet.be

ORCID: 0000-0003-4592-2298

DOI: http://dx.doi.org/10.12775/BPTh.2018.018
Biblica

et

Patristica

Thoruniensia

11 (2018) 3: 361-366

ISSN (print) 1689-5150

ISSN (online) 2450-7059

\title{
Biblical Thomism: What is Next?
}

\section{Tomizm biblijny. Co dalej?}

\section{Book review: Michael O'Connor, Cajetan's Biblical Commentaries. \\ Motive and Method, Brill, Leiden, 2017, xvi + 302p. \\ ISBN: 978-04-32506-7}

Keywords: medieval exegesis; Biblical Thomism; Thomas Aquinas; Cajetan; Reformation.

Słowa kluczowe: egzegeza średniowieczna; tomizm biblijny; Tomasz z Akwinu; Kajetan; Reformacja.

$\mathrm{U}^{\prime}$ p until now, ${ }^{1}$ and understandably so, Biblical Thomism has almost entirely focused itself on a historical and systematical analysis of St. Thomas Aquinas's commentaries on various books of the Bible by way of translations in various languages, numerous monographs and collected volumes on aspects of his biblical exegesis. ${ }^{2}$ In fact, Biblical Thomism constitutes, together with the emphasis on the patristic sources of St. Thomas and the renewed discovery of the commentatorial tradition of Thomism, one of the most vibrant features of contemporary Thomism. Although one should distinguish these three features (Scripture, Church Fathers and the commentatorial tradition), a separation would result in abstracting or detaching St. Thomas's thought from the tradi-

1 See J. Vijgen, The Future of Biblical Thomism: Reflections on the French translation of Thomas Aquinas's commentaries on Paul's Letters to the Philippians and the Colossians, pp. 213-219.

2 For a recent example see Towards A Biblical Thomism.: Thomas Aquinas and the Renewal of Biblical Theology, 299 p. 
tion that formed his work and subsequently brought his work to us. ${ }^{3}$ If, indeed, the unity of the Thomist Tradition is real, as the Dominicans Romanus Cessario and Cajetan Cuddy have convincingly shown, ${ }^{4}$ the future of Biblical Thomism will have to address the commentarial tradition of Thomistic exegetes from the early beginnings to such 20th century figures as Marie-Joseph Lagrange, O.P. (1855-1935), Paul Synave, O.P. (1888-1937), Ceslaus Spicq, O.P. (1901-1992), Pierre Benoit, O.P. (1906-1987) and others.

It is, therefore, with great excitement and gratitude that I have embarked on reading Michael O'Connor's monograph on Cajetan as a scholar of the Bible. ${ }^{5}$ Cardinal Cajetan, O.P. (1469-1534) is, of course, among Thomists a well-known figure, not the least because of his commentary on Thomas' Summa Theologiae, fortunately printed in the earliest volumes of the critical Leonine edition at the turn of the 20the century and therefore easily accessible. Less well-known is the fact that he is the author of "a million words of translation and commentary on most of the biblical text" (p. 1), taking advantage of the best results of Renaissance biblical humanism. The goal of the book is to give not only an overview of the impressive body of his biblical exegesis but also to argue that the reform of the Church by way of incorporating the findings of Renaissance biblical exegesis lied at the heart of Cajetan's project. In order to achieve this task Cajetan sought to arrive at a new Latin translation of the Bible on the basis of the Greek and Hebrew texts without, however, discarding the patristic and medieval textual traditions. Cajetan focuses almost exclusively on the literal sense of the text, which for him means not a "shallow "literalism" but an attention to what O'Connor calls "the literary richness in the text". O'Connor also challenges, convincingly, in my view, the conventional understanding of his motive for undertaking such a project. Rather than an apologetic defense of the Catholic truth (the Counter-Reformation view as it is called), Cajetan's motive was much subtler but also more "diffuse and inclusive: to make use of the textual critical tools provided by humanist scholars to contribute to a widespread renewal of Christian living" (p. 4).

The book consists of three parts. Part 1 (pp. 11-60) contains the best intellectual biography of Cajetan to date. The author describes the influence of the classical tradition by way of rhetorical theology, grammatical theology and poetic theology on the practice of theology and preaching in Renaissance Rome. Besides these elements, the author distinguishes a fourth element, i.e. "the en-

\footnotetext{
3 See J. Vijgen, Biblical Thomism: Past, Present and Future.

4 Thomas and the Thomists. The Achievement of Thomas Aquinas and His Interpreters.

5 Citations and references to O'Connor's monograph are given in brackets, followed by page numbers in the body of this review.
} 
during presence of scholasticism and, in particular, of the Dominican Thomas Aquinas. Certain elements of Aquinas's teaching were well-suited to the intellectual culture in Renaissance Rome: in general, his sense of order and beauty, wisdom and harmony in God's works; and more particularly, the way this sense of orderly providence could be articulated in terms of the papacy's monarchial role at the Church's centre. Aquinas was not only prominent but also the single strongest theological influence in Renaissance Rome" (p. 22). As the author notes, there is, in the early stages of his life, little evidence of "a future biblical specialist taking shape" (p. 23) although already in reading Aristotle Cajetan had shown himself to be sympathetic towards the need for accurate texts. As Master General of the Order he declares Scripture to be "at the centre of the intellectual life, reform, and mission of the Order to which he belonged" (p. 34). The author insightfully notes that such a stress on Scripture was not a novelty for him as a Dominican and disciple of St. Thomas. However, the remarkable developments in the first decades of the $16^{\text {th }}$ century in the area of Biblical Humanism by Reuchlin, Erasmus, Lefèvre d'Etaple, Valla, and others were also influential. The Dominicans also participated in this new approach to biblical studies with such figures as Agostino Giustiniani and Santi Pagnini. The author formulates the consensus that emerges in this period concerning the study of Scripture in four points: first, the need to revise the Vulgate; two, the importance of philology; third, the value of non-Catholic material and fourth the renewal of Christian life as its underlying motive (pp. 44-45). Once Cajetan is relieved of his manifold duties as Master and Papal diplomate, he will devote his time almost entirely to biblical commentaries from 1524 onwards until his death in 1534. In one of his first works in this regard, the Ientacula Novi Testamenti, literalis expositio, a series of comments on difficult passages, he fills in a gap which he had left open in his commentary on the Summa. Ten years earlier, he had remarked that Aquinas's reading of the Beatitudes in ST I-II, qq. 69-70 requires "frequent reading and meditation, rather than exposition". The entirety of his exegetical works, as produced in these later years, however, do not seem to be a "maverick hobby" or a "self-directed" project but rather an "explicit papal assignment", given that Cajetan himself notes that the Pope Clement VII made possible time and space to dedicate himself to these studies ("amplium temporis spatium ad dictandum mihi largiri") (p. 59).

The second part of the book (pp. 63-126) deals with the motives behind Cajetan's enterprise. It offers a reading of the biblical commentaries from 15241534 as a single corpus with the view of expounding Cajetan's explicit and implicit motives. Cajetan is concerned with offering both clarifications of difficult passages and with giving clergy and laity access to Scripture for assisting them in their spiritual and moral life. But he also implicitly has a lot to say in terms 
of "a diagnosis of the ills of the world and the Church, together with some indications of the remedies needed" (p. 73). A central place in these remarks is devoted to offering a sort of 'mirror for princes' [my term] of the Church. Such a mirror for princes includes the papacy as well (pp. 85-91). Unsurprisingly for a Dominican, considerable attention is devoted to the ministry of preaching. Equally interesting, in particular in light of a recent monograph on the issue, is the author's discussion of Cajetan's interpretation of the Beatitudes (pp. 9196). ${ }^{6}$ Regarding Cajetan's remarks on Islam and the faith of Ishmael in Genesis 16 , the author notes that these "illustrate a general tendency to irenicism" (p. 101) on the part of Cajetan. This feature notwithstanding, the "Lutheran problem" remains in view. However, what is "surprising" is "how infrequent such elements of Counter-Reformation [i.e. criticism of Luther] are" and "how restrained, measured and judicious they are" (p. 103). In fact, the normal pattern is to address errors where they arise but Cajetan, contrary to his treatises on these matters, will not enter into a more detailed discussion and argumentation. There is, however, one exception, i.e. the bread of life discourse in John 6 which was a "lightning rod for Eucharistic controversy" (p. 112) because of the positions of Zwingly and the Lutherans with which Cajetan takes issue. The last pages of this second part are therefore devoted to a chronological analysis of the three instances (Commentary on ST III, q. 80, a. 12 of 1519-1520, the Instructio for the Nuncio from 1525 and his commentary on John 6 from 1528), in which Cajetan discusses the question whether the discourse refers explicitly to the Eucharist. I agree with the author that in downplaying this connection (to the disagreement of Robert Bellarmine), Cajetan offers a dense and somewhat confusing argument.

Part three of the book (pp. 129-249) is concerned with the two methodological tools employed by Cajetan, i.e. a correction of the Latin translation on the basis of original language sources and a fresh commentary on this corrected text according to the literal sense, ignoring the Fathers and setting aside the many existing glosses. Regarding the first, the author deals with Cajetan's sources and in particular his use of Erasmus 1517 and 1519 Annotationes. With regard to his translations, the ideal is to offer a word for word translation, recognizing, however, the limits of this approach. Such a philological approach inevitably raises the question of authorship. Cajetan argues for multiple authorship regarding the Psalms, for the authorship of Moses for the Book of Job, whom he regards as an historical character, providing additional arguments to the ones given by St. Thomas. Cajetan goes so far as to attribute only sec-

6 See A. ten Klooster, Thomas Aquinas on the Beatitudes. Reading Matthew, Disputing Grace and Virtue, Preaching Happiness. 
ondary canonicity to the Letter to the Hebrews, i.e. "matters of faith may not be determined on the evidence of this book alone" ("Quo fit ut ex sola huius epistolae authoritate non possit si quod dubium in fide accideret determinari") (p. 159). Regarding the second tool, i.e. a commentary according to the literal sense, the author argues that "in Cajetan's hands, the literal sense is 'thicker', more flexible and multifaceted, capable of yielding substantial doctrinal, spiritual and moral insights." It is not simply a first level, pointing to the other three spiritual levels but "something rather different. Cajetan's understanding of "literal' is more literary than literalist" (p. 169) [emphasis mine]. A central aspect regards the idea of the historical contextuality of words as well as literary contextuality. Indicative of Cajetan's Thomism is the fact that he locates the Tetragrammaton not in some mystical revelation of the Trinity as some of his humanist contemporaries but in the metaphysical tradition: the name defines the God of Israel as the fons essendi, insisting on both the freedom of God as well as on His involvement and providential care. He also argues for a simultaneous creation in Genesis 1, noting, however, that the six days are not fiction but expression of six grades of perfection of the created world. In the chapter on the harmony and sufficiency of Scripture the author raises and discusses a number of topics, such as the identification of Mary Magdalene in Luke and John, the use of the Psalms in the New Testament, the importance of oral and liturgical tradition (e.g. the scriptural origins of the sacrament of extreme unction on pp. 210-211), the role of philosophy in scriptural exegesis, etc. His treatment of Matthew 19:9 and of the Pauline privilege (pp. 212-216) will be of interest not only to scholars of history because of the challenges it poses to the "Catholic tradition" (p. 212) ending up with "formulating a new axiom", i.e. "What God has joined together, God alone can separate" (p. 216). Extensively (pp. 224-232) treated are the topics of immortality of the soul, predestination and the priority of will over intellect because "in his later years, Cajetan seems to have grown in skepticism about the abilities of unaided reason to grasp the deeper mysteries of life" (p. 224). What is striking in Cajetan's treatment of all these topics is the tentative nature of many of his conclusions, due I would gather, to what the author calls his "methodological blend" (p. 237) of scholasticism and humanism. The final chapter of this third part deals with the reception of Cajetan's scriptural exegesis and is aptly entitled using a phrase of a $17^{\text {th }}$ century historian of the Council of Trent, Sforza Pallavicino who wrote that his commentaries were "applauded neither by heretics nor by Catholics". In fact, his fellow Dominican Ambrosius Catharinus interceded with Pope Clement VII for censuring his biblical commentaries (eventually writing an entire work, the Annotationes in commentaria Caietani, against Cajetan) and theologians at the Sorbonne started an investigation. In his response Cajetan, among other 
things, leaves the judgment regarding his position on marriage to the Church. While the Council of Trent addressed many problematic issues raised by $\mathrm{Ca}-$ jetan's critics, his reception remained problematic both in the Order (e.g. Melchior Cano) and in general.

The book under review arrives at an important goal, i.e. it convincingly nuances the traditional binary of Cajetan the Thomistic theologian versus the Counter-Reformation prelate and analyses the results of a "humanist Thomism" (p. 252). One could question, however, whether the all-too concise history of biblical exegesis in the final pages (pp. 255-258) and the attempt to place Cajetan's achievements within this history would not have profited from a more detailed and nuanced treatment. For instance, it is highly questionable that the contemporary debate in biblical exegesis rests on an assumption that there is a polarization between the "scientific....analysis of the academy and the Christian interpretation of the Churches" (p. 257). While it seems correct to say that Cajetan "resists this polarisation and complicates the picture," it would be equally correct to call attention to the costs of resisting such a polarisation.

These critical remarks only concern the last pages of a book which will become a classic study in the thought of Cardinal Cajetan and which will offer Biblical Thomists the ways to expand their research, material and inspiration for comparative studies. For this, one owes the author an enormous debt of gratitude.

\section{References}

Cessario R., Cuddy C. (eds.), Thomas and the Thomists. The Achievement of Thomas Aquinas and His Interpreters, Fortress Press, Minneapolis MN 2017.

ten Klooster A., Thomas Aquinas on the Beatitudes. Reading Matthew, Disputing Grace and Virtue, Preaching Happiness, Peeters, Leuven 2018.

Roszak P., Vijgen J. (eds.), Towards A Biblical Thomism: Thomas Aquinas and the Renewal of Biblical Theology, Ediciones Universidad De Navarra, SA., Pamplona 2018.

Vijgen J., The Future of Biblical Thomism: Reflections on the French translation of Thomas Aquinas's commentaries on Paul's Letters to the Philippians and the Colossians, Biblica et Patristica Thoruniensia 9 (2016) 3, pp. 213-219. DOI: http://dx.doi. org/10.12775/BPTh.2016.030.

Vijgen J., Biblical Thomism: Past, Present and Future, Angelicum 95 (2018) 1, forthcoming. 